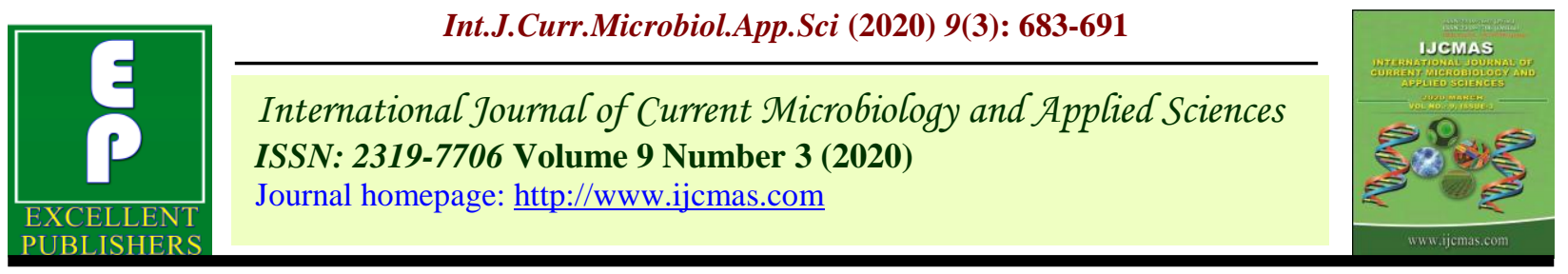

Case Study

https://doi.org/10.20546/ijcmas.2020.903.082

\title{
Study of Hand Grip Strength of Rural and Urban Household Performing House Hold Work
}

\author{
Abha Singh $^{1 *}$ and Tajesvita ${ }^{2}$ \\ ${ }^{1}$ Department of Family Resource Management Collage of Home Science N.D.U.A.T, \\ Kumar Ganj Ayodhya, Uttar Pradesh, India, \\ ${ }^{2}$ Family Resource Management Collage of Home Science N.D.U.A.T, \\ Kumar Ganj Ayodhya, Uttar Pradesh, India \\ *Corresponding author
}

\begin{tabular}{l} 
Ke y w o r d s \\
Drudgery, cooking \\
food, mopping \\
floor, cleaning, \\
utensils, hand \\
strength, rural house \\
hold. \\
\hline Article Info \\
$\begin{array}{l}\text { Accepted: } \\
\text { 05 February } 2020 \\
\text { Available Online: } \\
\text { 10 March } 2020\end{array}$ \\
\hline
\end{tabular}

\section{A B S T R A C T}

Women are the back bone of household activities. They spend daily almost 13-14 hours on household work and caring the family members. The household activities consists of cooking, washing clothes, washing utensils and mopping the floor. The rural women even carry out farm work (sowing, Transplanting, harvesting and Threshing) while urban women are not involved in farm work. However no matter how much they do and how much time they spent in performing, these activities, it will go un-noticed because of its non-economic value. But the drudgery involved in performing these activities are very high. The strain due to the drudgery impairs the health of household women, which affects the quality and time spent in work. The physiological discomfort caused by drudgery reduces the hand grip strength and causes other kinds of fatigue. Therefore there is a need to understand the extent of changes in the hand grip strength of women from rural and urban areas due to cooking, mopping, cleaning of utensils and washing of clothes. Hand grip strength affects the time taken to perform a job. In this study only cooking, mopping, cleaning utensils and washing clothes are included because these four activities are common both in rural and urban households.

\section{Introduction}

Although several studies have been made on house hold work and drudgery but there is lack of a comparative study of urban and rural household performing household work. Kumari and Dayal (2009) ${ }^{(1)}$ have reported that heavy work like mopping floor, grinding masala and cleaning kitchen and window causes more strain. Khatoon ${ }^{(3)}$ et al., (2007) found in their study, that maximum hand grip strength was $25.59 \mathrm{~kg}$ for right hand, and for both hand it was $16.09 \mathrm{~kg}$. Vinay and chawdhari (2005) ${ }^{(2)}$ also have reported that 
household activities demand a high degree of Physical activities leading to fatigue. Similarly Awasthi (2002) ${ }^{(3)}$ has reported that size of family takes more time in cooking and more drudgery prone activity Even Bimla $\mathrm{dal}^{(6)}$ (2006) have reported that cooking and washing vessels are more drudgery prone.

Although so far reviewed studies have confirmed that household activities do cause drudgery which affects the performance of work performed by household women. But these studies have not reported that effect of cooking, mopping, utensils cleaning have comparatively how much impact on urban and rural women performing this activities.

This study will try to answer the question by comparing the amount of hand grip strength between rural and urban household As mentioned earlier we have taken only those activities which are common in both, urban and rural households.

\section{Scope of Study}

This study will generate knowledge and insights which may contribute more understanding on hand grip strength which may help to improve the hand grip leading to more work and reductions in drudgery.
Though there are more activities causing drudgery but in this study only three activities which are common to both urban and rural household are undertaken.

The main objectives of this study includes, to found out the demographic and socioeconomic background of rural and urban households. To find out the level of hand grip strength of rural and urban households who are involved in house hold work.

To ascertain the level of hand grip strength of right and left hand.

To get the percentage change in hand grip strength of right and left hand.

\section{Limitations of Study}

It covers only cooking, mopping, cleaning utensils and washing clothes only.

The data is only from district Faizabad, hence result may not be generalized for whole state.

\section{Materials and Methods}

\section{Conceptual Model}

On the review of literature and our own experiences, the following conceptual model was developed.

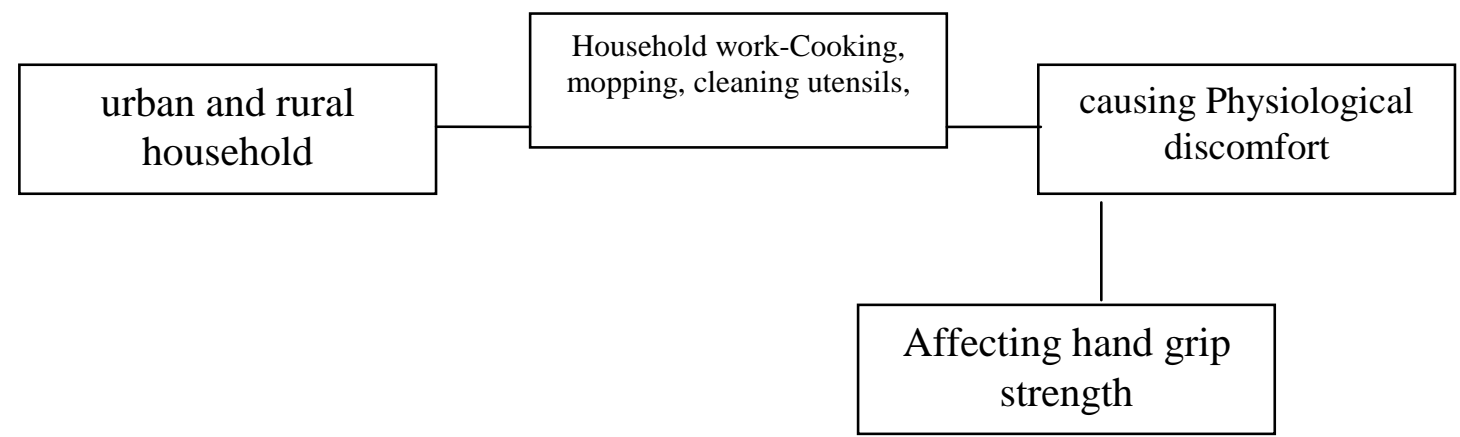

Fig,1 Conceptual model 


\section{Research Design}

\section{Selection of site of the study}

For this study, Faizabad district has been selected purposely. It is near to the agricultural university and the researcher has more deeper knowledge about Faizabad district.

\section{Selection of Urban and Rural area}

One village from rural area and one urban ward was selected purposely

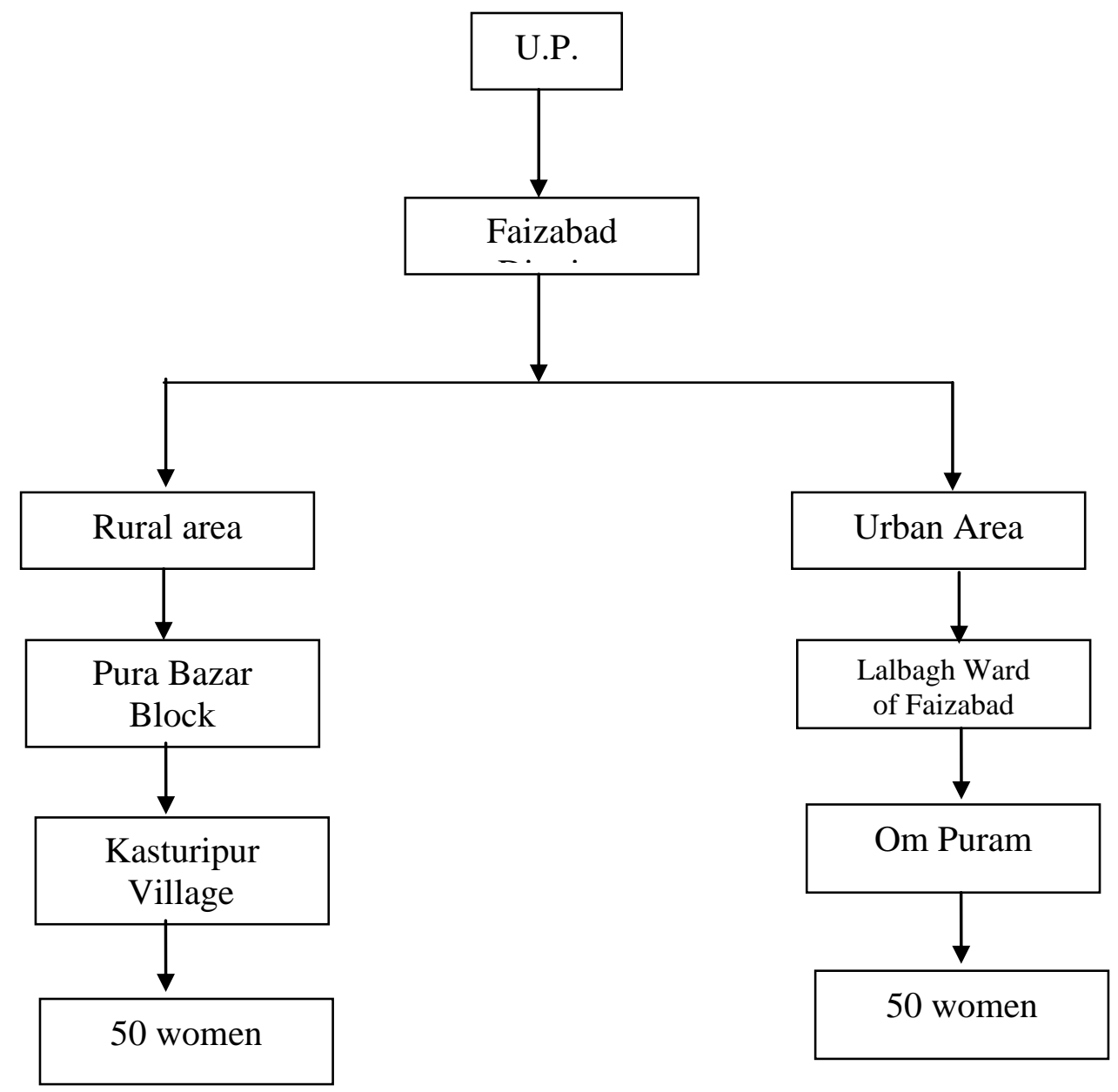

Fig,2 Shows the sampling Process

Sample of Size

50 women from urban and 50 women from rural areas were selected randomly.

\section{Tools for data collection}

A Questionnaire was designed to interview selected respondents. Besides interview, observation technique was also used.

\section{Pilot study}

Before giving the final shape to questionnaire, a pilot study was conducted in area which was not selected for the study. Data was collected from 10 percent of the sample size respondents from out of pilot project area. The pilot study was conducted to see the feasibility and gaps in the questionnaire and necessary modification were made in the questionnaire. 


\section{Data Collection}

An interviewer visited the selected village and ward area to build rapport with the selected respondents. After building rapport, interview was conducted.

\section{Variable selected}

There are two types of variable : one is independent and the other is dependent variable. selected variables are presented in here

\section{Independent variable}

1. Education

2. Size of family

3. Type of family

4. Caste of family

5. Income of family

6. Type of house.

\section{Dependent variable}

Hand grip strength

\section{Statistics Used}

Only standard deviation and mean Statistics and percentage value have been used in this study.

\section{Background of Respondents}

For the understanding of background of the respondent, only 6 variable have been included from the independent variable and one variable from the dependent variable. The details is presented in Table-1

\section{Education}

Table-1 clearly shows that on education variable there are more illiterates in rural households compared to urban household respondents. Their number among rural household is 40 percent while in urban household it is 10 percent, similarly in rural area 20 percent household are educated up to primary level but in urban area their number is 10 percent. The number of household educated upto junior high school, only 10 percent are from rural area where as in urban area their number is $30 \%$.

Thus, there is a trend that in rural area there are more illiterate compared to urban area. In case of rural area there are 10 percents educated up to secondary level but their counterpart in urban area are 40 percent.

\section{Variable - Size of family}

The urban household respondent has smaller size of family while in rural households respondents have bigger size of family. Again Almost $20 \%$ of the family from rural area have a family size of 4 or less than 4 members but their counterpart have 5-7 members and in urban area it is 30 percent. Similarly in rural area respondents have 8 or more members in their family but in urban area are only 26 percent.

\section{Variable - Type of family}

Now a days there is a a trend to have nuclear family. 60 percent of urban respondents have nuclear family while 30 percent of rural respondents have nuclear family with regard to joint family, 60 percent of rural respondents have joint family when only 18 percent of urban respondent have joint family. In urban area $22 \%$ of families had extended family while in rural area it is only $8 \%$.

\section{Variable - Caste of Respondents}

The 50 percent of urban respondents are from upper caste whereas rural household respondents hence only 20 percent. Similarly the number of $\mathrm{OBC}$, in urban respondents 
family 30 percent but rural respondents have 40 percent of joint family. The number of SC/ST family is urban households is 20 percent while as rural households have 40 percent of them.

\section{Variable - Monthly Income}

There are $80 \%$ household whose income is up to Rs. 10,000 or less per month but in urban respondents families are 20 percent similarly. Those earning between Rs. 10001 to Rs. 15000 , their number in urban households is 10 percent but in rural households it is 20 percent. The number of those earning 15001 to 20000 their number in urban households is 20 percent but there is none is in this category from the rural area. Thus the figure reflects that urban households are richer than the rural households.

\section{Variable - Type of House}

60 percent rural respondents households have Kuchcha house while 16 percent of urban respondents have Kuchha house. Similarly 24 percent of urban respondents have mixed house but from rural area $20 \%$ of them have mixed house.

As far as Pucca house is concerned 60 of urban respondents have Kuchha house but only 20 percent of rural house holds have the same kind of house.

\section{Hand Grip Strength}

The changes in hand grip strength is presents in table which shows that what is hand grip in right and left hand for urban and rural household when they perform cooking, mopping, washing utensils.

\section{Physical Parameter of respondents}

Physical and Physiological character of the subjects selected for the study are presented in table-2. The mean age found to be $25.01 \pm 3.567$ years and ranged from 20 to 59 years in the urban area on the other hand. The average age of respondents from rural area is $20.55 \pm 4.102$ and ranged from 21 to 45 years. The body weight of respondents was $64.52 \pm 9.093$ and it ranged from 41 to 94 for the urban respondents while rural respondents from rural area have average weight of $56.92 \pm 7.723$ and ranged from 35 to 75 years.

The height of respondents from urban area ranged from 147 to 165 and average weight was $155.69 \pm 6.15$ for rural respondents The weight ranged from 140 to 167 while average weight was $150.81 \pm 3.26$ with regards to body mass, in urban respondents it ranged from 15.57 to 32.95 and the average body mass index was $22.27 \pm 2.44$ but for rural respondents if ranged from 14.36 to 30.98 and average body mass index was $17.77 \pm 1.94$. In case of $H R$ rest the beats per minutes for urban respondents was $76.56 \pm 6.89$ and it ranged from 72.95 to 81.35 , average weight was $66.16 \pm 3.170$ and it ranged from 68.80 to 86.97.

The HR max beats/min for urban respondents was $135.69 \pm 7.45$ and it ranged between 125.78 to 153.85 . But among the rural respondents the HR max beats/min 125.78 to 153.85. and among the rural respondents it was $125.87 \pm 5.15$ and it ranged from 118.10 to 144.69. Table-3 shows that mean value of maximum grip strength of different hands of urban women before and after cooking activity. The mean score of before work of urban women respondents, the hand grip strength of right hand is $44.92 \pm 2.52 \mathrm{Kg}$ whereas after the respondents of work it was observed to be $42.27 \pm 2.91$ and percentage change is 5.89 in right hand. In the left hand before any work, hand grip value is $45.15 \pm 2.16$ and after cooking the mean grip value is $42.46 \pm 2.99$ and percentage change is 5.95 . 
The hand grip strength of left hand of urban household is $45.14 \pm 2.16$ before the work performance and after work performance, their grip strength of left hands $45.15 \pm 2.16$ and the percentage change is 5.95 .

However the right hand grip strength of rural respondents before performing cooking is $47.35 \pm 5.76$ while after the cooking, the left hand grip strength is $45.10 \pm 6.18$ and percentage change is 4.71 . The left hand grip strength of rural respondents before work is $46.32 \pm 1.29$ while the same after is $44.32 \pm 9.65$ and percentage change is 3.71 . It is clear that urban women have more percentage change compared to women from rural area.

Among the right hand of urban respondents the mean value of hand grip strength is $47.82 \pm 3.82$ before performing the mopping. However after performing the mopping the mean value comes to $42.77 \pm 2.51$ and the percentage change is 10.56 . In case of left hand grip the value of hand grip strength comes to $46.35 \pm 3.66$ before performing the mopping while after performing the mean value comes to $45.16 \pm 5.89$ and the percentage change in 2.56 .

The situation of rural household as reflected in the table has shown that the rural women respondents before doing mopping have the mean value of right hand grip strength is 44.25 \pm 7.12 . However their right hand grip strength after performing the mopping work is $41.19 \pm 8.10$ and the percentage change in right hand in urban household is 10.56 .

similarly the rural household working before the mopping has the mean value of their left hand $43.83 \pm 6.29$. However after performing the mopping, the grip strength of left hand, the mean value comes to $38.47 \pm 4.55$ and percentage change is 9.97. As far as percentage change in the value of hand grip among the urban and rural household in their right and left, is concerned their percentage change in right hand is 10.55 , in left hand it is 2.56 for urban women and for rural household it is 7.02 percent for right hand and 9.79 for left hand.

\section{Hand grip strength of washing utensils}

The hand grip strength of urban and rural house wives is presented in table 5 .

\section{Percentage change of grip}

As evident from the table 7, There is no significant difference in cooking in right and left hand of urban household but in rural household, there is a significant difference between right and left grip strength.

As far as mopping is concerned in right hand the grip strength in urban women is 10.56 percent but in left hand it is only 2.56 when it comes to rural households, the percentage change in right hand is 7.02 which is lower than urban household but in left hand the change is 9.97 percent in cooking and the change which is more or less the same as right hand of urban area but much higher than the left hand percentage change of urban women.

The utensil cleaning, percentage change is very high compared to all three household activities. However in urban the percentage change is higher in right hand and left hand it is high but lower than right hand.

In rural household in right hand, the grip strength change is very low. In both urban area and urban household percentage change is very high in right hand grip strength. In utensil cleaning percentage change in left hand is high. 
Table.1 Background information of selected respondents

\begin{tabular}{|c|c|c|c|c|}
\hline \multirow[t]{2}{*}{ S.No. } & \multirow[t]{2}{*}{ Variable } & \multirow[t]{2}{*}{ Particular } & Urban & Rural \\
\hline & & & $\begin{array}{c}\text { No. of } \\
\text { respondent }\end{array}$ & $\begin{array}{c}\text { No. of } \\
\text { respondents }\end{array}$ \\
\hline 1 & Education & $\begin{array}{c}\text { Illiterate } \\
\text { upto Primary level } \\
\text { up to Junior high school } \\
\text { up to higher secondary }\end{array}$ & $\begin{array}{l}10(20) \\
5(10) \\
15(30) \\
20(40)\end{array}$ & $\begin{array}{l}30(60) \\
10(20) \\
5(10) \\
5(10)\end{array}$ \\
\hline 2 & Size of family & $\begin{array}{c}\text { Upto } 4 \text { members } \\
\text { upto } 5-7 \text { member } \\
8 \text { and more members }\end{array}$ & $\begin{array}{l}22(44) \\
15(30) \\
13(26)\end{array}$ & $\begin{array}{l}10(20) \\
20(40) \\
20(40)\end{array}$ \\
\hline 3 & Type of family & $\begin{array}{c}\text { Nuclear } \\
\text { Joint } \\
\text { Extended } \\
\end{array}$ & $\begin{array}{l}30(60) \\
9(18) \\
11(22)\end{array}$ & $\begin{array}{c}16(32) \\
30(60) \\
4(8)\end{array}$ \\
\hline 4 & Caste of Family & $\begin{array}{l}\text { Upper cast } \\
\text { OBC } \\
\text { SC/ST }\end{array}$ & $\begin{array}{l}25(50) \\
15(30) \\
10(20)\end{array}$ & $\begin{array}{l}10(20) \\
20(40) \\
20(40)\end{array}$ \\
\hline 5 & $\begin{array}{l}\text { Monthly income } \\
\text { of the family }\end{array}$ & $\begin{array}{c}\text { upto } 10,000 \mathrm{Rs} \\
10,001 \text { to } 15,000 \mathrm{Rs} \\
15,001 \text { to } 20,000 \mathrm{Rs} \\
\text { Above } 20,000\end{array}$ & $\begin{array}{l}10(20) \\
5(10) \\
10(20) \\
25(50)\end{array}$ & $\begin{array}{c}40(80) \\
10(20) \\
\quad- \\
-\end{array}$ \\
\hline 6 & Type of house & $\begin{array}{l}\text { Kachha } \\
\text { Mixed } \\
\text { Pucca }\end{array}$ & $\begin{array}{c}8(16) \\
12(24) \\
30(60)\end{array}$ & $\begin{array}{l}30(60) \\
10(20) \\
10(20)\end{array}$ \\
\hline
\end{tabular}

Figures in parent thesis indicate percentage value

Table.2 Physical Parameter of respondents

\begin{tabular}{|c|c|c|c|c|c|}
\hline \multirow{2}{*}{ S.No. } & \multirow{2}{*}{ Parameter } & \multicolumn{2}{|c|}{ Urban } & \multicolumn{2}{c|}{ Rural } \\
\cline { 3 - 6 } & & Range & Mean Value & Range & Mean Value \\
\hline $\mathbf{1}$ & Age & $20-59$ & $25.01 \pm 3.567$ & $21-45$ & $20.55 \pm 4.102$ \\
\hline $\mathbf{2}$ & Body Weight & $41-94$ & $64.52 \pm 9.093$ & $35-75$ & $56.92 \pm 7.723$ \\
\hline $\mathbf{3}$ & Height & $147-165$ & $155.69 \pm 6.16$ & $140-167$ & $150.81 \pm 3.26$ \\
\hline $\mathbf{4}$ & Body Mass Index & $15.57-32.95$ & $22.27 \pm 2.44$ & $14.36+3.98$ & $17.77 \pm 1.94$ \\
\hline $\mathbf{5}$ & HR Rest beat/min & $72.95-87.35$ & $76.55 \pm 6.89$ & $68.80-86.97$ & $66.16 \pm 3.170$ \\
\hline $\mathbf{6}$ & HR Max beat/min & $125.78-153.85$ & $135.69 \pm 7.45$ & $118.10-144$ & $125.87 \pm 5.15$ \\
\hline
\end{tabular}

Table.3 Hand grip strength $(\mathrm{kg})$ of respondents during cooking

\begin{tabular}{|c|c|c|c|c|c|}
\hline \multirow{2}{*}{ S.No. } & \multirow{2}{*}{ Particulars } & \multicolumn{2}{|c|}{ Urban } & \multicolumn{2}{c|}{ Rural } \\
\cline { 3 - 6 } & & $\begin{array}{c}\text { Right hand } \\
(\mathbf{K g})\end{array}$ & $\begin{array}{c}\text { Left Hand } \\
(\mathbf{K g})\end{array}$ & $\begin{array}{c}\text { Right hand } \\
(\mathbf{K g})\end{array}$ & $\begin{array}{c}\text { Left Hand } \\
(\mathbf{K g})\end{array}$ \\
\hline $\mathbf{1}$ & Before work & $44.92 \pm 2.52$ & $45.15 \pm 2.16$ & $47.35 \pm 5.76$ & $46.03 \pm 1.29$ \\
\hline $\mathbf{2}$ & After Cooking & $42.27 \pm 2.91$ & $42.46 \pm 2.99$ & $45.10 \pm 6.18$ & $44.32 \pm 9.65$ \\
\hline $\mathbf{3}$ & $\begin{array}{c}\text { Percentage change } \\
\text { in grip strength }\end{array}$ & 5.89 & 5.95 & 4.75 & 3.71 \\
\hline
\end{tabular}


Table.4 Hand grip strength of respondents before and after mopping

\begin{tabular}{|c|c|c|c|c|c|}
\hline \multirow{2}{*}{ S.No. } & \multirow{2}{*}{ Particulars } & \multicolumn{2}{|c|}{ Urban } & \multicolumn{2}{c|}{ Rural } \\
\cline { 3 - 7 } & & Right hand & Left Hand & Right hand & Left Hand \\
\hline $\mathbf{1}$ & Before mapping & $47.82 \pm 3.82$ & $46.35 \pm 3.66$ & $44.25 \pm 7.12$ & $43.83 \pm 6.29$ \\
\hline $\mathbf{2}$ & After mapping & $42.77 \pm 2.51$ & $45.16 \pm 5.89$ & $41.19 \pm 8.10$ & $38.47 \pm 4.55$ \\
\hline $\mathbf{3}$ & Percentage Change & 10.56 & 2.56 & 7.02 & 9.97 \\
\hline
\end{tabular}

Table.5 Hand grip strength of respondents during utensils cleaning

\begin{tabular}{|c|c|c|c|c|c|}
\hline \multirow{2}{*}{ S.No. } & \multirow{2}{*}{ Particulars } & \multicolumn{2}{|c|}{ Urban } & \multicolumn{2}{c|}{ Rural } \\
\cline { 3 - 6 } & & Right hand & Left Hand & Right hand & Left Hand \\
\hline $\mathbf{1}$ & Before work & $47.14 \pm 9.37$ & $44.68 \pm 7.65$ & $46.14 \pm 6.92$ & $45.89 \pm 6.75$ \\
\hline $\mathbf{2}$ & After work & $39.51 \pm 8.11$ & $38.17 \pm 9.83$ & $36.70 \pm 9.83$ & $40.91 \pm 9.74$ \\
\hline $\mathbf{3}$ & Percentage Change & 16.18 & 14.57 & 20.45 & 10.85 \\
\hline
\end{tabular}

Table.6 Percentage of cooking, mopping and utensil cleaning strength Percentage change

\begin{tabular}{|c|c|c|c|c|c|}
\hline \multirow{2}{*}{ S.No. } & \multirow{2}{*}{ Particulars } & \multicolumn{2}{|c|}{ Urban } & \multicolumn{2}{c|}{ Rural } \\
\cline { 3 - 6 } & & Right hand & Left Hand & Right hand & Left Hand \\
\hline $\mathbf{1}$ & Cooking & 5.89 & 5.95 & 4.75 & 3.71 \\
\hline $\mathbf{2}$ & Mopping & 10.56 & 2.56 & 7.02 & 9.97 \\
\hline $\mathbf{3}$ & Utensil cleaning & 16.18 & 14.57 & 20.45 & 10.85 \\
\hline $\mathbf{4}$ & $\begin{array}{c}\text { Percentage change in } \\
\text { urban \& rural }\end{array}$ & 20.08 & & 19.38 & \\
\hline
\end{tabular}

The conclusion is that cooking has much less percentage change in hand grip strength for urban and rural house wife but utensil cleaning has high percentage of change. The percentage change in hand grip is highest in utensil cleaning among rural and urban respondent both in left and right hand. However cooking has least percentage change in urban respondents in their right and left hand.

In utensil cleaning among urban respondent the percentage changed in hand grip strength of right hand is 6.18 and in left hand it is 14.57 in rural household. The percentage of grips in a right hands is 5.6 and in left hands it is 13.82. However overall there is no significant difference in the hand grip strength of rural urban household while performing the work. In cooking the percentage change is more or less the same as in right and left hands of urban area but significantly higher then left had percentage of rural women. The utensil cleaning percentage change is very high compared to all 3 activities. However in the urban area percentage change is higher in right hand and in left hand it is high but lower than right hand. The conclusion is that cooking has much percentage change in rural household. Considering each activities separately there is difference between rural household as urban household as well as right and left hand grip strength.

\section{References}

1.Kumari P and Dayal R (2009) Ergonomic evaluation of selected kitchen tools Humanizing work and work environment (HWWR) PP. central 
Institute of agricultural engineering

Bhopal, India.

2.Sandhu P, J. Dhillon, J. Gill, M.K. Borahs (2001) Cardio Vascular Response of young Indian Female While Performing Selected Domestic Activities, Indian Journal of Physiology and Allied Sciences 55 : PP 102-113.

3.Khatoon I, B. Verma, and Dayal R (2007) Grip Assessment Of Rural Women Performing Dish Washing Activity in Deoria District and Industrial Ergonomics, vol5 PP 125-131 Allied Publishers Pvt. Ltd. New Delhi.

4.Chaudhari N and Vinay D (2005) Determination Of Optimum Work Surface Heights For Kitchen Based On Ergonomic Principles Pros Humanizing work and work Environment (HWWR) 69 PP IT Gauhati.

5.Awasthi N. (2002) Assessment of Physical Features and Quality Of Rural Kitchen, MSc. CSA, Univ. Of Agri \& Technology Kanpur PP 137.

6.Bimla PK, M Dilbagi, K.S. Rana R Gandhi's (2006) Drudgery Activity In Rural Home A Work Study \& Rural India 69 (10-11) PP 192-194

7.Khatoon J, B Verma and Dyar R (2007) Grip Assessment of Rural Women performing Washing Activity in Daveoria Dist U.P, Development in Agriculture and Industrial Ergonomics Vol 5 PP 125 to 133 Allied Publisher Pvt.Ltd New Delhi.

8.Grandjean E. (1980). Ergonomics of the
Home. London: Taylor and Francis Ltd.

9.Gupta, G. and Nandini, N. (2015). Prevalence of low back pain in non working housewives of Kanpur, India. International journal of occupational medicine and environmental health. 28 (2):313-320.

10.Lwakiri, K.; Kunisue, R.' Satoyama, M. And Udo, H. (2008) Postural support by a standing aid alleviating subjective discomfort among cooks in a forward bent posture during food preparation. $J$. Occup. Health 50:57-62.

11.Kaur, S.; Kaur, H. and Kaur, S. M. (2012) Analysis of Postures Adopted by Rural and Urban Women While Working in Kitchens. International Conference on HWWEE, G.B.P. University, Pantnagar Udhampur, Utranchal, India

12.Khare, T. and Sharma, P. (2013) Assessment of physiological cost of work for the workers performing kitchen related standing activities in restaurants. Asian $J$ Home Sci. 8(1):38-42

13.Mukhopadhayay, P. and Srivastava, S. (2010) Ergonomic risk factors in some craft sectors of Jaipur. Journal of the human factors and ergonomic society of Australia, 1 (24).

14.Sultana, S. and Prakash, C. (2013) Benefits of using ergonomic kitchen design for today's homemaker. Golden, Research Thought 3(6):1-7.

15.Maria lis, A.; Black, K. M.; Korn, H. and Nrdin, M. (2007) Association between sitting and occupation LBP. European Spine J 16:283-298.

\section{How to cite this article:}

Abha Singh and Tajesvita. 2020. Study of Hand Grip Strength of Rural and Urban Household Performing House Hold Work. Int.J.Curr.Microbiol.App.Sci. 9(03): 683-691. doi: https://doi.org/10.20546/ijcmas.2020.903.82 